\title{
Urban expansion and the formation of technogenic deposits in tropical areas: The case of Araguaína city
}

\author{
Carlos Augusto Machado', delagnesse@uft.edu.br
}

\begin{abstract}
Technogenic deposits are formed with the materials produced by the human activity and direct or indirect deposition of sediments resulting in artificial bodies with an own dynamic in each environment. Among the problems, the formation and expansion of the technogenic deposits in the Araguaína city, north of Tocantins state (Brazil), may be subject to the economic cycles and technogenic resources in the last decades. The present study aims at two main aspects, at first a short discussion about the technogenic deposits worldwide will be made and then our aim will be analyzing will be made about the different types of inorganic, chemical, organic and terrigenous deposits in different environments: terrestrial, fluvial and lagoon. The applied methodology was based on the review of the literature, characterization of the study area and urban expansion, identification of satellite images and the structural and morphologic characterization of the technogenic materials. The results point at the link between the types of materials and phases of urban expansion, which mean that the deposits have a higher concentration of organic material and dominance of inorganic materials. Due to the necessity of adjusting the relief and soil for the construction, some areas suffered severe topographic changes and great deposition of technogenic materials. The future perspectives, based on the present conditions, indicate an increasing number and variety of technogenic deposits in some study areas.
\end{abstract}

Keywords: urban expansion, technogenic deposits, structural and morphologic characterization.

\section{La expansión urbana y la formación de depósitos tecnogénicos en zonas tropicales: el caso de la ciudad de Araguaína}

\begin{abstract}
RESUMEN
Los depósitos tecnogénicos se forman por la acumulación de los materiales producidos por la actividad humana y por la deposición de sedimentos que resultan, directa o indirectamente, en cuerpos artificiales, pero con su propia dinámica en cada entorno. Entre los problemas asociados está la formación y expansión de los depósitos tecnogénicos de la ciudad de Araguaína, estado de Tocantins (Brasil), que estarán sujetos a los ciclos económicos y los recursos tecnológicos en las últimas décadas. Este estudio apunta a dos aspectos principales, en primer lugar, una breve discusión sobre el tema de los depósitos tecnogénicos mundiales y segundo, analizar la formación de diferentes tipos de depósitos de residuos químicos inorgánicos, orgánicos, terrígenos y en diferentes ambientes, como el terrestre, fluvial y lacustre. La metodología está fundamentada en la revisión de la literatura, en la caracterización del área de estudio y la expansión urbana, en la identificación de imágenes de satélite y caracterización estructural y morfológica de los materiales tecnogénicos. Los resultados indican una relación entre los tipos de materiales y las etapas de expansión urbana, es decir que el depósito antiguo tiene una concentración mayor de material orgánico presente y el predominio con la deposición de materiales inorgánicos. Debido a la necesidad de ajustar el suelo y la topografía para las construcciones, algunas zonas sufrieron cambios topográficos graves y grandes deposiciones de material tecnogénico. Las perspectivas para el futuro, dadas las condiciones actuales, apuntan a una creciente cantidad y variedad de depósitos tecnogénicos en determinados puntos del área de estudio.
\end{abstract}

Palabras clave: expansión urbana, depósitos tecnogénicos, caracterización morfológica y estructural.

Recibido el 14 de octubre de 2013, aceptado el 10 de junio de 2014.

1 Federal University of Tocantins, Department of Geography, Paraguay Avenue s/n, Campus Cimba, Araguaína City, Tocantins State-CEP: 77.838.824. 


\section{INTRODUCTION}

In urban areas, the changes in the geomorphologic and pedologic forms caused by the changes in the urban areas mainly by the civil constructions and engineering work produce anomalies in the surface producing changes in the environment in the form of solid remnants deposits, landfills, rectifications and excavations causing innumerous problems to the local environment. Such changes caused by the human activities are denominated Technogenic Deposits, which are made of materials from many origins of human activity.

The understanding of the influence of such deposits in structuring and in the dynamics of the environment can demonstrate the negative effects about the following elements: soil, water, relief, vegetation and weather and provide subsidies for the managers and staff to work with urban planning. Each changed or suppressed element stops exercising a specific function and added to the modification of other elements create a synergy and increase the problems in urban areas (MACHADO 2012).

According to TER-STEPANIAN (1988), the technogenic deposits are characterized by the great variety, different features, diversity in their composition and variation in their thickness, which characterize an independent genetic group, whilst analogies with natural deposits can be drawn. Some deposits accumulate a high amount of organic matter, generally urban remnants and others of inorganic matter as the ones derived from remnants of construction materials and remnants of mining.

The environment that is so far conditioned by natural processes, start incorporating artificial elements from the human activity, which increase its influence in the population growth and technological rate. The humanaltered area is modeled in order to attend the human activities through the cultural and technological evolution of each time (OLIVEIRA 2005, GOUDIE 2006, CSIMA 2010). In some millennial cities as Rome, the urban area is continuously re-built through the existing buildings from the ancient times and then, foundations and vestiges are partially or totally incorporated to the environment (LEHMANN \& STAHR 2007).

GOUDIE (2006) highlights the cases of metropolis as Hong Kong, Dubai and Tokyo that move forward to the sea to expand their economical land, through the moving of tons of civil construction remnants, soils and in some cases domestic solid remnants in marine water causing an imbalance in the water. The technogenic deposits located in the waterfront are subject to addition and removal of materials due to the waves. And in some cases, they are subject to subsidence due to the accommodation of the material because of the underground water.

The technogenic deposits created by human activities are incorporated to the local environment covered with the sedimentation in wetlands and hard to be detected due to the vegetation growth which will cause some issues for the built houses using these materials. It should be highlighted that the public administrations don't have an effective policy to control and evaluate the disposal of solid and liquid remnants until the present moment and this negligence has increased in the last 10 years (MACHADO \& RODRIGUES 2011).

The structure and organization of an environment is the result of the evolution of an area that has been processed through thousands and millions of years. As vertically as evenly, the structure of the elements can aggregate the result of innumerous events that acted in the past guaranteeing a better heterogeneity of factors to be studied as a base for city planning development. The study developed by NEBER et al. (2006) in the city of Cologne in Germany was based on the geological and geomorphologic evolution in the urban area to indicate the direction of the urban growth and can help in the problems related to the technogenic deposits. The planning staff usually circumscribes the studies in a descriptive way and not only in an analytical way, detecting only the small and located impacts. 
According MACHADO (2011) the recovery of a degraded area requires a long time in some cases, as in the case of the landfills resulting of human action and depending on the affected area and on environmental conditions (soil, weather and vegetation). Even with the adoption of some recovering and conservation areas, a satisfactory conservation doesn't always happen, making the environmental planning indispensable for the development of economic activities in agreement with the availability of environmental resources.

The remnants from construction and demolition in the civil construction contain innumerous chemical elements that in contact with the pedological layer and with the water are dissolved and incorporated to the environment being absorbed by the plants, microorganisms, fishes and human beings. See Table 1 for the chemical elements present in each of the waste materials.

The understanding of the actual behavior in the pedological layer with the insertion of materials and creation of technogenic deposits is vital for understanding the dynamics of the physical, chemical and biological processes of this artificial body and the differences in the behavior of the present materials.

According to the age of the deposit, the types of materials can differ from each other due to the technological substitution in new materials and also due to the fact that some materials are economically viable for recycling or reusing, the lack of aluminum, zinc and copper in more recent deposits, commonly removed by scavengers of recycling companies.

The process of regenerating the areas with technogenic deposits depends on the type of material. In general, deposits with civil construction materials will need more time for the decomposition to happen than deposits with organic elements, but the polluting effect can be prolonged in both cases.

The solid remnants resulting from the implementation, transformation and demolition of the urbanization process are deposited in ravines, gullies, wastelands, wetlands or in streets with no pavement for the compaction in the riverbed. These areas don't have any of the necessary equipments for the deposition of remnants, fact that will contribute with the mobilization of the solid and liquid generated in the decomposition of the organic and inorganic materials. Besides this fact, it is verified that a strong superficial drainage concentrated in the periods of intense rainfall drags a great amount of solid remnants to the wetlands, increasing the accumulation of materials in the riverbeds and in the small sedimentation flat lands originating the technogenic deposits (MACHADO 2012).

Table 1. Problems caused in the environment with the Waste of Civil construction remnants. Tabla 1. Problemas causados en el medio ambiente por los residuos de Restos de construcción CIVIL.

\begin{tabular}{|c|c|}
\hline Types of material & Effects produced in the environment \\
\hline Cement 1/2 & Crust Formation in the Ground, Soil and Water Acidity \\
\hline Lime $^{1}$ & Soil and Water Acidity \\
\hline Iron $^{2}$ & Iron-Bacteria Formation and Modification of Water Chlorine \\
\hline Wood $^{2}$ & Decomposition of Nitrogen in the Soil. \\
\hline Plastic $^{2}$ & Slow Decomposition, Presence of Toxic Substances \\
\hline Ceramics $^{2}$ & Presence of Toxic Chemical Products and Porosity Reduction \\
\hline Aluminum $^{2}$ & Chronicle Intoxication \\
\hline Clay2 (Tiling) $^{\text {Crust Formation }}$ \\
\hline Amianthus2 $_{\text {(Tiling) }}$ & Lung Diseases (Asbestosis, Cancer and Mesothelioma) \\
\hline Paint $^{2}$ & Incorporation of Heavy Materials in Human Beings and Water Toxity \\
\hline Glasses $^{2}$ & Acidity (Sodium carbonate) and Crust Formation (Silica and Feldspats) \\
\hline
\end{tabular}

Sources: (1) SILVA et al. (2007), (2) ASSOCIAÇÃO BRASILEIRA DE NORMAS TÉCNICAS (ABNT). 
The stabilization and incorporation rates in the Technogenic Deposits areas can vary meaningfully, according to BOSCOV (2008): "The population growth, modifications in the demographic distribution and in the population habits, changes in economy, technological evolution, among other factors, provoke changes in the composition of the urban solid remnants. The technological evolution, for example, is continuously introducing new products in the urban solid remnants, such as plastics, batteries, fluorescent lamps, chemical products and chips. An example is the city of São Paulo, where the level of rotten materials has decreased from $82,5 \%$ in 1927 to $58 \%$ in 2003 , while inexistent plastics in the composition of the urban solid remnants until the $60 \mathrm{~s}$ represented $16 \%$ of the total urban solid remnants in 2003 (IPT 2003; LIMPURB 2003) apud (BOSCOV 2008:36).
The technogenic deposits haven't only proliferated in tropical areas, but their problems date back centuries and decades in Europe, Asia and Middle East and their great heterogeneity requires appropriate methods and techniques for treating each situation. In the last decade, the world has been watching changes in the geographic space in large scales, which means that human interventions in short scales provoked projects for human occupation with great modifications and changes in the terrestrial and marine areas, citing the constructions in the Middle East, specifically Dubai in the United Arab Emirates - the creation of a huge artificial island named Palm Beach with about $30 \mathrm{~km}^{2}$ of area with the removal and redeployment of thousands tons of rocks and soil and if this project succeeds new artificial islands will be built. Other cases of high human intervention are the islands in the Pacific Ocean as the Maldives formed by corals, often filled with earth for the urban expansion for public work, see figures 1 and 2 .

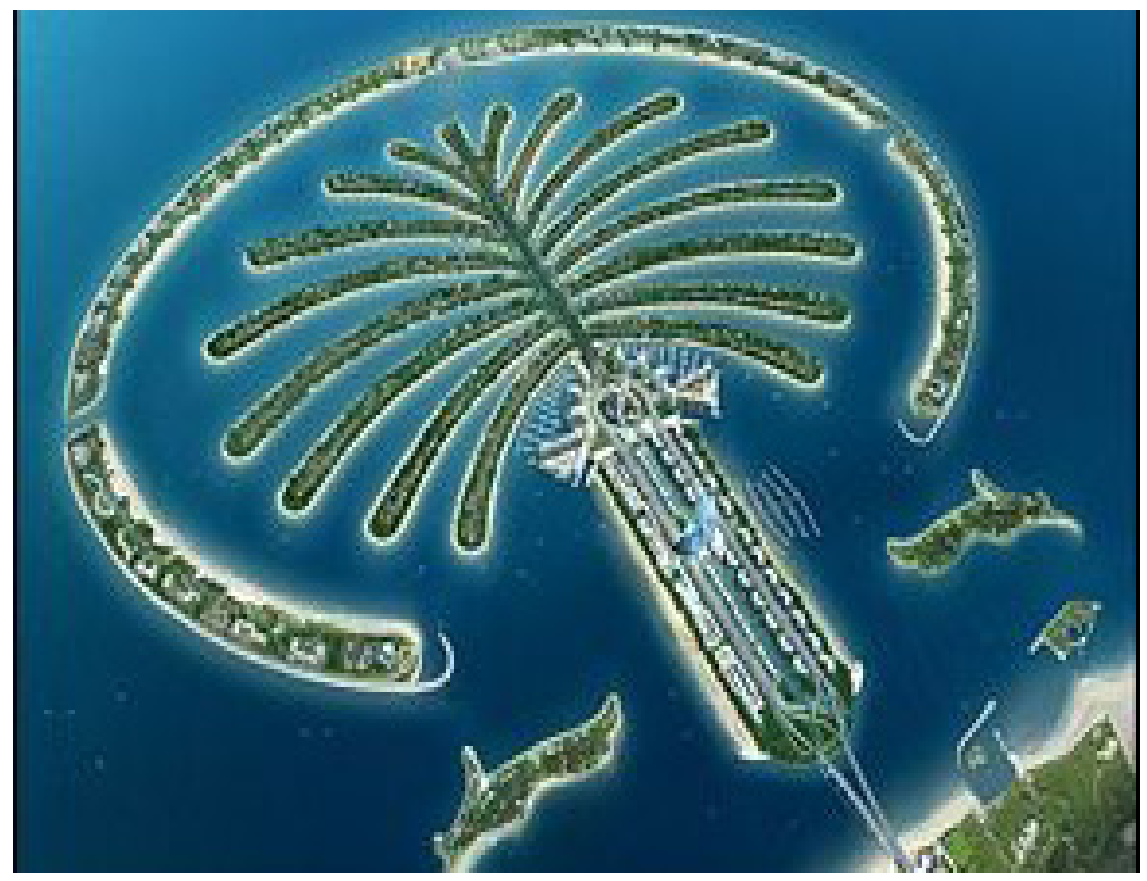

Fig. 1. Artificial Island Palm Beach, Dubai, Source: ilhasmaldivas.vilabol United Arab Emirates Source: realestate.theemiratesnetwork.com.

Fig. 1. Isla artificial de Palm Beach, Dubai. 


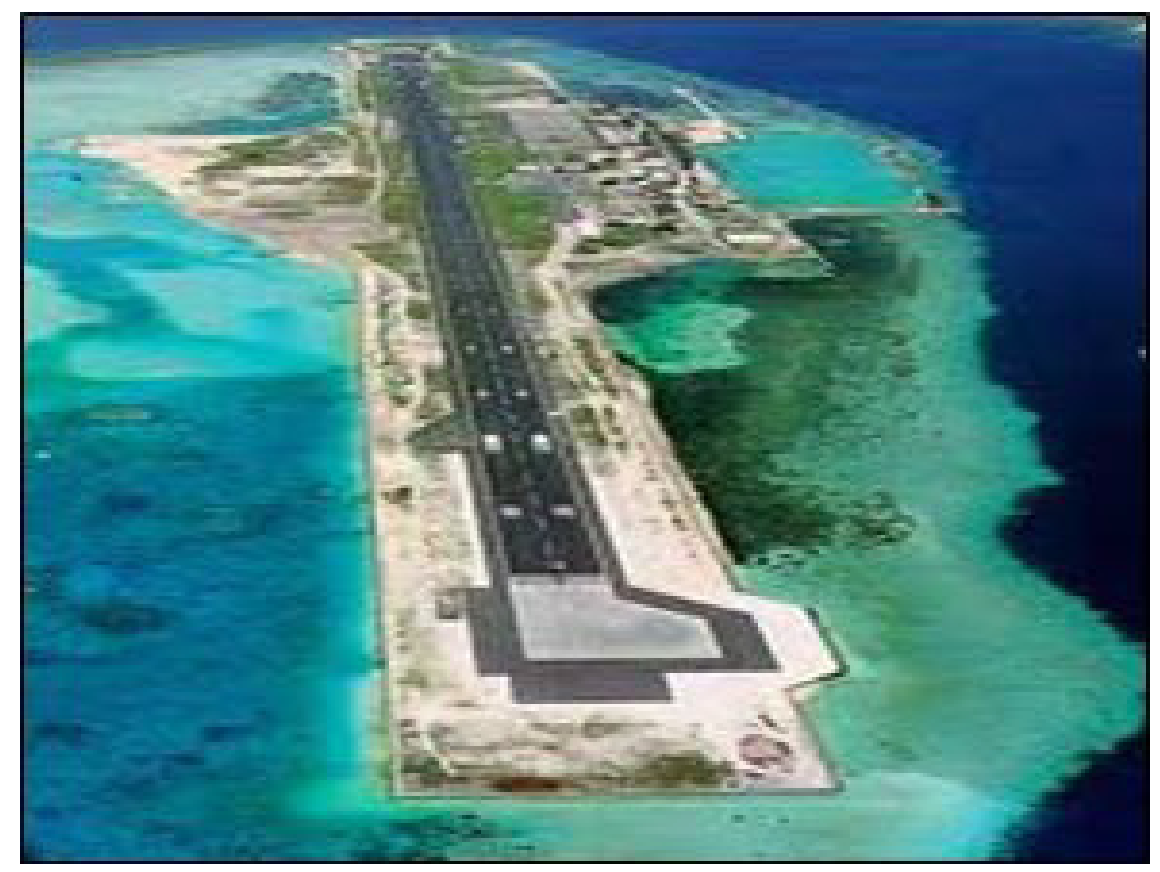

Fig. 2. Corals Urbanization, Maldivas Island United Arab Emirates.

Fig. 2. Urbanización de los corales, Isla Maldivas.

The environment, which is so far conditioned by natural processes, start incorporating artificial elements of human activities which increases its influence due to the population growth and technological rates. The anthropized area is shaped to attend the human activities along the cultural and technological evolutions. In some millennial cities as Rome, the urban area was continually re-built through the time over the existent structures and its foundations were discovered. Also, vestiges in the format of deposits of materials were partially or completely incorporated to the area.

The present study aims at two main aspects, at first a short discussion about the technogenic deposits worldwide will be made and then our aim will be analyzing will be made about the different types of inorganic, chemical, organic and terrigenous deposits in different environments: terrestrial, fluvial and lagoon in the Araguaína city.

The city of Araguaína, located in the North of Tocantins state, see figure 3 , was chosen as a case study for technogenic deposits. This city attracted investments and businesses which generated a fast development since 1975 with the pavement of the road BR-153 and the installment of several enterprises promoted by the Superintendência de Desenvolvimento da Amazônia (SUDAM) - Superintendence of Development for the Amazon and Banco da Amazônia S.A. (BASA) - Bank of the Amazon. Such investments resulted in an expansion in the urban areas and in demographic growth generating innumerous environmental issues, such as the technogenic deposits (MACHADO \& OLIVEIRA 2005). 


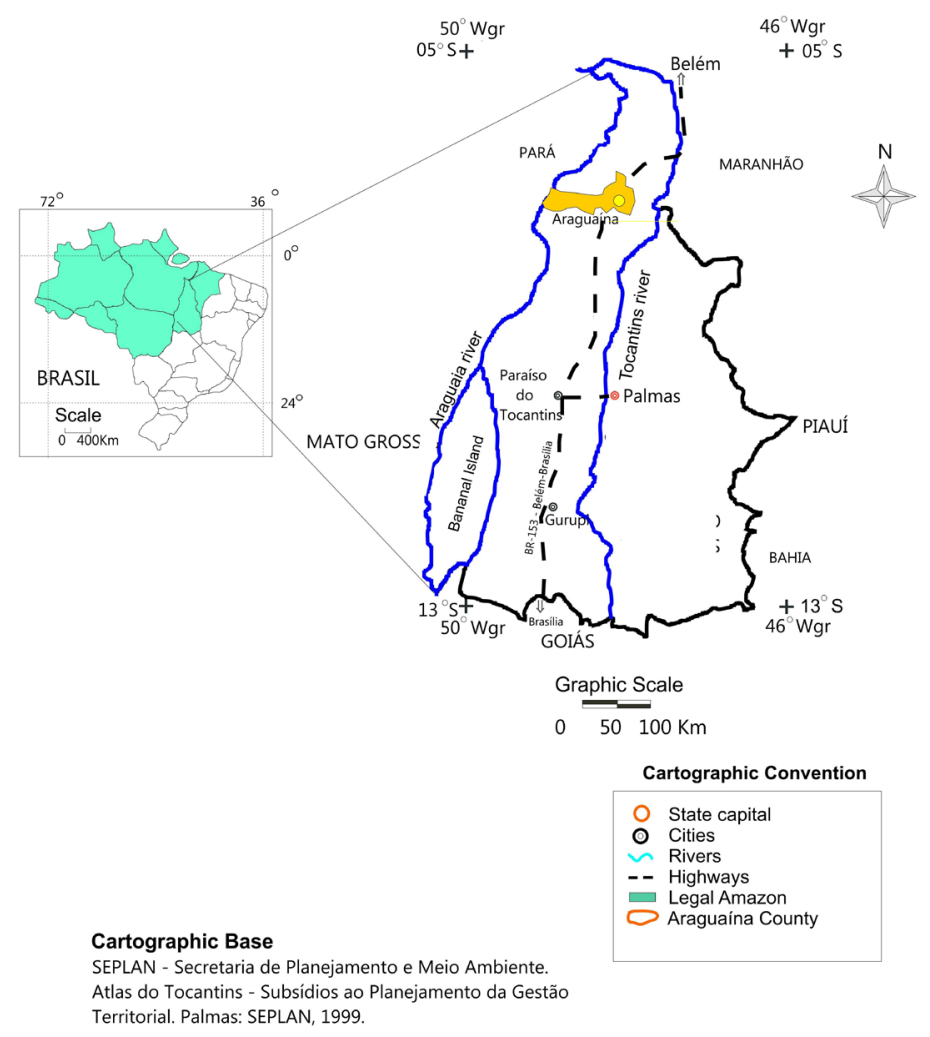

Fig. 3. Map of Localization of Araguaína City.

Fig. 3. Mapa de ubicación de la ciudad de Araguaína Source: TOCANTINS (2004).

\section{MATERIALS AND METHOD}

The appointed problems and the expansion of the technogenic deposits in the world were reproduced based on the works of OLIVEIRA (2005), GOUDIE (2006), LEHMANN \& STAHR (2007) and CSIMA (2010).

The environmental characterization of the study highlights the geological and geomorphologic aspects elaborated based on the findings of TOCANTINS (2004) and MACHADO et al. (2008).

The elaborated motion for the classification of the technogenic deposits by CHEMEKOV (1983) and FANNING \& FANNING (1989) used in almost all of the studies take into account aspects related to the genesis and material composition. In this sense, the classification motion of this study will be based in the type of material originally suggested by TER-STEPANIAN (1988) as terrigenous, chemical, organic, inorganic and heterogeneous.

The method used in this work was developed by MACHADO (2012) based on the following steps: characterization of the study area, identified through satellite images, classification of deposits, work field (area measurements, collecting sediment and tecnogenic materials) and laboratory analysis.

Different from the other studies about the Technogeous, the elaborated 
classification for this work will consider the constituting materials and the addition of the environmental factor of deposition (terrestrial, fluvial and lagoon) based on the work of MACHADO (2012), once the dynamic of the deposit will be modified according to the characteristics of each area.

The location of the Technogenic Deposits was based on the surveys performed in areas of olden landfills, areas that suffered interventions through public construction work (mainly sewerage) and in new areas.

The location of the Technogenic Deposits by satellite images is hard due to the fact that the materials are generally covered by landfills, vegetation and civil construction. In order to make the identification of these areas easier, some indirect factors were considered, such as: the changes in the drainage system, fluvial deposits, changes in the geomorphologic features and differences in the density and kind of vegetation. Based on these facts, the location of the Technogenic Deposits were possible through the analysis of aerial photography from the INSTITUTO BRASILEIRO DE GEOGRAFIA E ESTATÍSTICA (IBGE) of 1969 and compared to the images taken from the satellite SPOT in different scales from 2005 and 2011 available on Google Earth ${ }^{\circledR}$.

For this present work, only deposits with a bigger area than $500 \mathrm{~m}^{2}$ were selected. Smaller areas were not considered due to the difficulty in identifying the satellite images and also because they aren't much meaningful for the study. The measurement of the analyzed areas were obtained through the use of the software ARCGIS. The interpretation of the satellite images help in locating and identifying the deposits and will also be used for the evaluation of the environmental impacts.

A GPS (model Garmin Hcx) was used for determining the coordinates of the deposits. The measurement was obtained through the use of a measuring tape.
The soil gradation analysis used for characterizing the existing sediments in the technogenic deposits was based on the parameters defined in the work of SUGUIO (1973) and realize in the Geomorphology and Erosion Laboratory from the Federal University of Uberlândia. The parameter color was defined through the use of the Munsell letter. The other analyzed parameters were: structure of the layers (plan, blocks or irregular), consistency (friable or compact) and concretion (type and format). SUGUIO (1973) emphasizes that the composition and disposal of the deposited remnants are essential for the understanding of the features of unconsolidated deposits.

For the lab analysis, samples of 500 gr of each layer / profile were selected and sifted in order to separate the sediments and technogenic materials to be analyzed.

Due to the lack of a classification regarding the size of the technogenic materials (fragments or concretions), three categories were adopted according to the majority of the analyzed remains in the studied profiles in Araguaína. These categories are:

- small $(0-5 \mathrm{~cm})$, medium $(5 \mathrm{~cm}-10 \mathrm{~cm})$, large $(>10 \mathrm{~cm})$.

The solid remnants generated by the urban activities in the city of Araguaína are from the two main types, the first one is derived from domestic, commercial and industrial garbage (mainly plastics, wood and paper) and the second one is derived from the civil construction (mainly bricks, shingles, ceramics and concrete).

The composition and percentage of the domestic solid remnants were obtained through data collected by Litucera Company: Cleaninng and Engeneering, responsible for the collection and dispatch of the remnants. 


\section{RESULTS}

Formation of technogenic deposits: the case of Araguaína city

The fast urban expansion of Araguaína in the two last decades favored the occupancy of new areas, mainly next to the wetlands of the many rivers that cross the city. The city administration doesn't have a normative inspection or an inspection regarding the environmental planning for the use of the soil. A strong political influence of the economical agents is verified and this influence promotes the opening of new lots, not only civil work in permanent areas of preservation. Just the action of the state environmental agency Instituto de Natureza do Tocantins (NATURATINS) can inhibit environmental damages. This agency is associated to the state, which has an environmental speech but ends up acting according to economic reasons.

The biggest changes in the Araguaína city, go through two periods of intense urban modification. The first one (between 1975 and 1985) with the construction of Belém-Brasília Highway (BR-153) and the intense prospecting in Serra Pelada, point of departure and supply for innumerous people. According to the INSTITUTO BRASILEIRO DE GEOGRAFIA E ESTATÍSTICA (IBGE) in the census of 1970, Araguaína population doubled in this period from 48.000 inhabitants to 98.000 inhabitants and its urban area expanded considerably, however without an appropriate infrastructure, that ends with the decline of prospecting and with the migration to the newly founded capital of Palmas, due to the detachment of the state of Goias. In the second expansion moment, after a 10-year-growth, from 1999, the city started receiving investments coming from universities and other companies, aiming at technical and mechanical support for the agriculture and exportation of grains (soy and corn). Such improvements inflate the real estate market that consolidates in 2006 with a huge operating budget for civil work and house financing generating a huge growth that remains until nowadays.

The structure of the area where Araguaína is located is characterized by sedimentary rocks formed by wind of Sambaíba Formation (215 m.a), marine sedimentary of Motuca Formation (240 m.a) and a basalt band of Mosquito Formation (190 m.a). In sedimentary areas, the morphogenesis has sculptured a relief with topographical amplitude between 260 and 300 meters, hills with declination between 7 and 15\% and extensive interfluves connected with some relieves (TOCANTINS 2004).

The pedological covering presents the predominance of yellow Latosoils and Quartz-sand Neosol both with a dystrophic profile with a high susceptibility to erosive processes with no vegetation of the existing Cerrados stricto sensu. In the magmatic areas, the wavy hills with declination between 5 and $20 \%$ are predominant and extensive interfluves with the dominance of purple eutrophic and resistant Latosoils against the erosion (MACHADO 2005).

The most critical area due to the urban expansion with formation of technogenic deposits, see figure 4, is located in the watershed of Neblina brook, which crosses downtown and is currently being a target for many geomorphologic, pedological and hydrological changes due to many civil work that change its drainage with rectification, canalization, narrowing and widening of the river channel. 


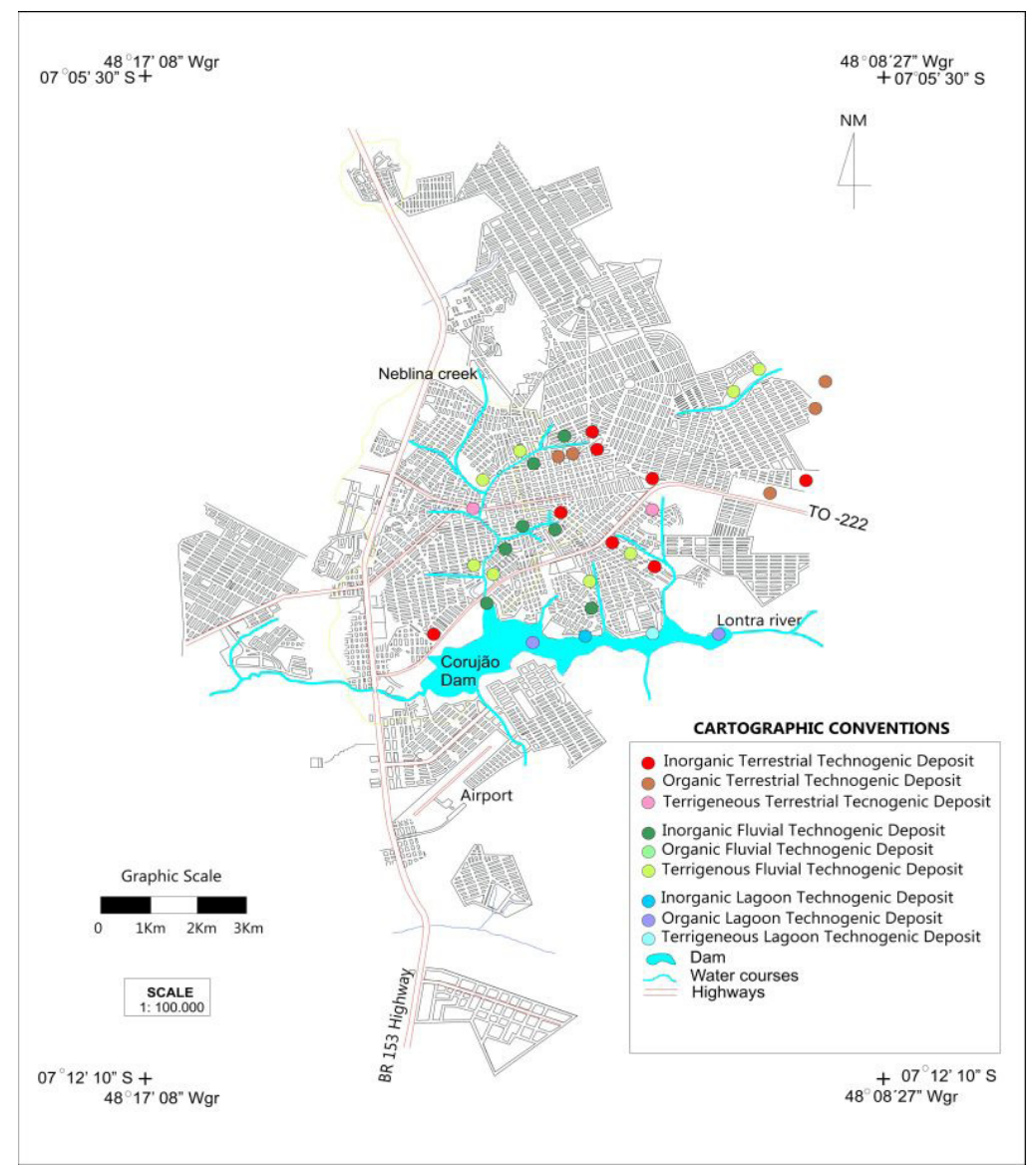

Fig. 4. Map of main Araguaína technogenic deposits.

Fig. 4. Mapa de los principales depósitos tecnogénicos de Araguaína Cartographic base: PLANO DIRETOR DE ARAGUAÍNA (2006).

The environmental dynamic in the urban area of Araguaína is subject to two seasons determined by the regional weather. The first one with the presence of the morphogenesis occurs in the summer with intense water activity promoting a strong movement of sediments and water, being more incisive where the Quartz-sand Neosol dominates, located in the east and northwest of the city and less intense in the areas covered by the clayish soil in the south and southeast. In the second period, due to the dry weather, the environmental processes have less intensity due to the irrelevant results of rainfall (MACHADO \& RODRIGUES 2011).
The solid remnants resulting from the creation, transformation and destruction of the urbanization are deposited in erosions, wastelands, wetlands or in streets with no pavement for the compaction of the riverbed. The areas that lack the necessary equipments for the disposal of remnants will be submitted to some environmental impacts, which will probably happen with the infiltration of solids, gases and liquids generated by the decomposition of the organic and inorganic materials. Besides this fact, it is verified that the superficial drainage, concentrated in the periods of high rainfall, drags a certain amount of solid remnants to the wetlands, increasing the accumulation of materials in the bottom of the riverbeds and in the flat lands of sedimentation. 
The technogenic deposit analyzed in the low water of the Neblina brook has an area of $33.383 \mathrm{~m}^{2}$, see figure 5 , and with $96 \mathrm{~cm}$ of depth showing many layers in a brown shade, due to the different levels of iron oxide in the water and arising from Quartzsand Neosol and existing Nitossolos in the water shed. According to the information gotten from the population of the area, the time for the formation of this deposit is probably 20 years and it has been expanding constantly due to the fast siltation of the brook that will be presented in the item regarding the lagoon technogenic deposits.

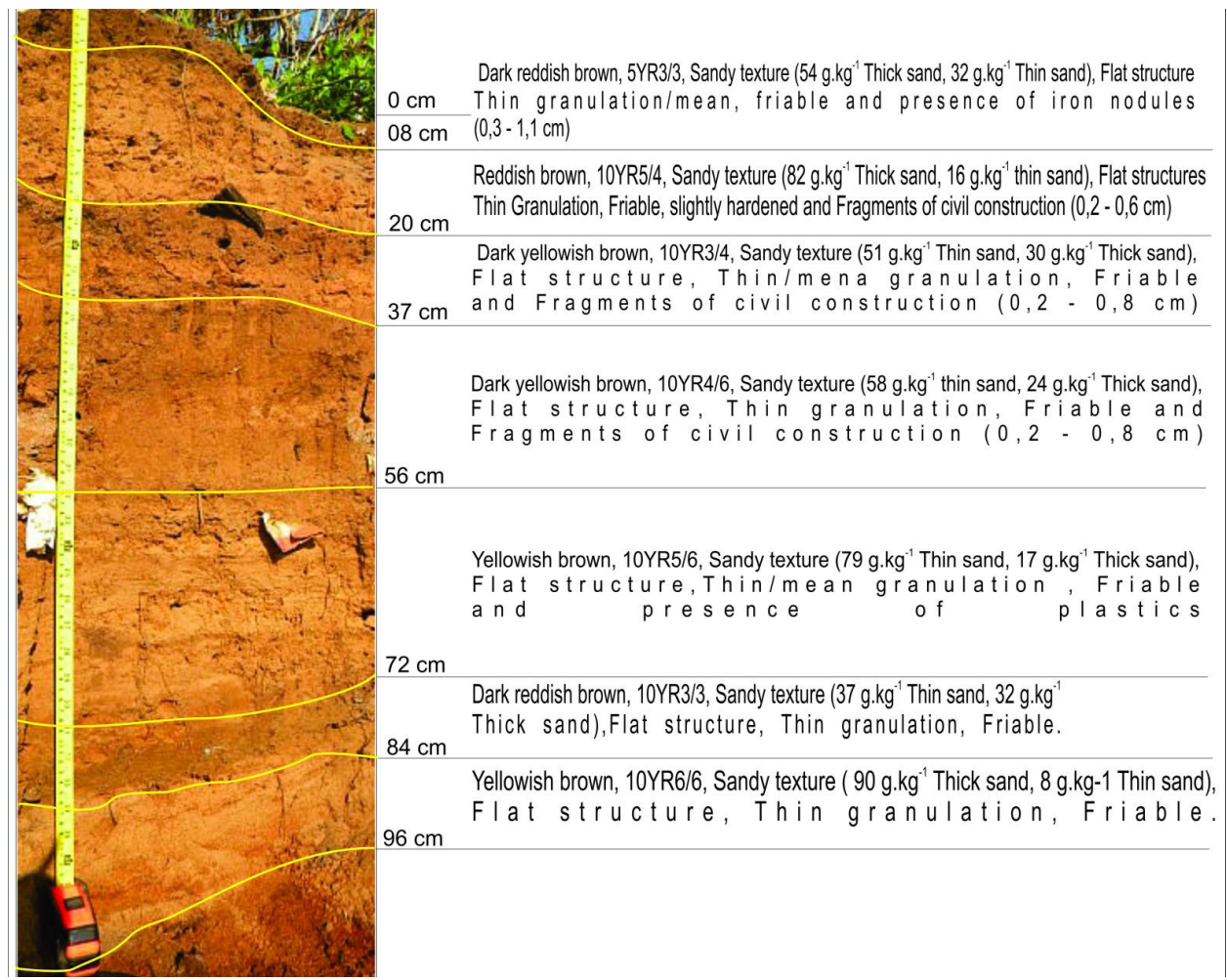

Fig. 5. Profile of Terrigeneous Fluvial Technogenic Deposit, Neblina creek.

Fig. 5. Perfil de Depósitos Tecnogénicos Fluvial Terrígeno, en corriente Neblina Coordinates: $7^{0}$ 12' 12" 56 S / 480 13' 16" 51 Wgr / (MACHADO 2012).

The seven existing layers in this structure present homogeneity of factors as: brown color, sandy texture, friability and small fragments, having a plan orientation in the deposit, which is reinforced by the radicular structure of grass and trees with up to 4 meters and high density showing the good fertility of the material.
There are technogenic deposits in almost all of the water courses that cross the urban area due to the high volume of sediments transported by the water and to the diversity and dimensions of fragments dissolved and adduced in the headwaters, producing a mosaic of different colors and layer combinations. 
The existence of the terrigenous fluvial deposits in fluvial areas result from the increasing siltation due to the constant inundation, mainly after the elevation of the level for the construction of Corujão dam in the 1970s. These deposits are composed by horizontal layers alternating clayish, sandy, organic sediments and fragments of construction material and urban garbage, which is often mobilized by the action of the fluvial water, see figures 6 and 7.

Most of the technogenic deposits in the city of Araguaína are located next to the headwaters or in more accented topography that are occupied by houses and irregular lots made of unstable materials, that will cause problems in the structure of the houses in some time. In some cases the deposited material was covered with sediments of the most elevated areas in the watersheds hiding the problem that will only be identified when a public work is accomplished in the area.

In some cases, the removal, remobilization and addition of materials form a small but extensive superficial cover that expands as the water carries the materials down the watershed. The built houses in this area present some cracks on the walls, problems in the foundations and some families are somehow compensated in the future. This fact refers to the east side of Araguaína city, where the districts Jardim das Flores, Patrocínio, Morada do Sol I and II had the popular houses implemented by the city and national government knowing that these areas were a deposit of solid remnants. In the city of Araguaína, the technogenic deposits are presented in some cases as a superficial layer with $30 \mathrm{~cm}$ thick, with sandy expressions that with the compaction, decomposition and sedimentations is mixed with the pedologic layer forming a hard superficial horizon.
While analyzing the changes in the city of Araguaína it is necessary to consider that before the foundation and expansion of the urban area, the space was occupied by small farms used for cattle breeding promoting the partial or total removal of the vegetation and favoring the erosion and leaching of the soil by the pluvial water, as well as the compaction of the soil contributing for changes in the elements and environmental processes, that will be added to an intense city modification later.

The fluvial technogenic deposits are results of the water courses drainage or silting and represent the smallest number, but they have BID extensions in the city of Araguaína with only four areas located in the mid-course of the Neblina and Cimba brooks. These areas, even with the canalization and the siltation over the water suffer with the inundations and floods with a considerable deposit of sediments, organic materials and urban garbage. The nature of the Quartz-sand Neosol in all over the watershed extension facilitates the dragging of a great amount of sediments to the wetlands resulting in the siltation.

In the rainy periods, the impact of the high volume of water in the tropical areas of the Amazon, as the infiltration and elevation in the phreatic level make the technogenic material used in wastelands unstable provoking innumerous problems to the houses and buildings in the areas, besides the problems with the inundation. Due to the problems with the buildings, some private work next to the brook was abandoned after the injuries were verifying.

The materials deposited in the old gullies and wastelands are mobilized by the strong superficial drainage in the rainy seasons and then stocked in the wetlands, see figure 8, which is stabilized by the vegetation growth. The construction of houses over this type of deposits is very common and they commonly present some problems in their structure. 


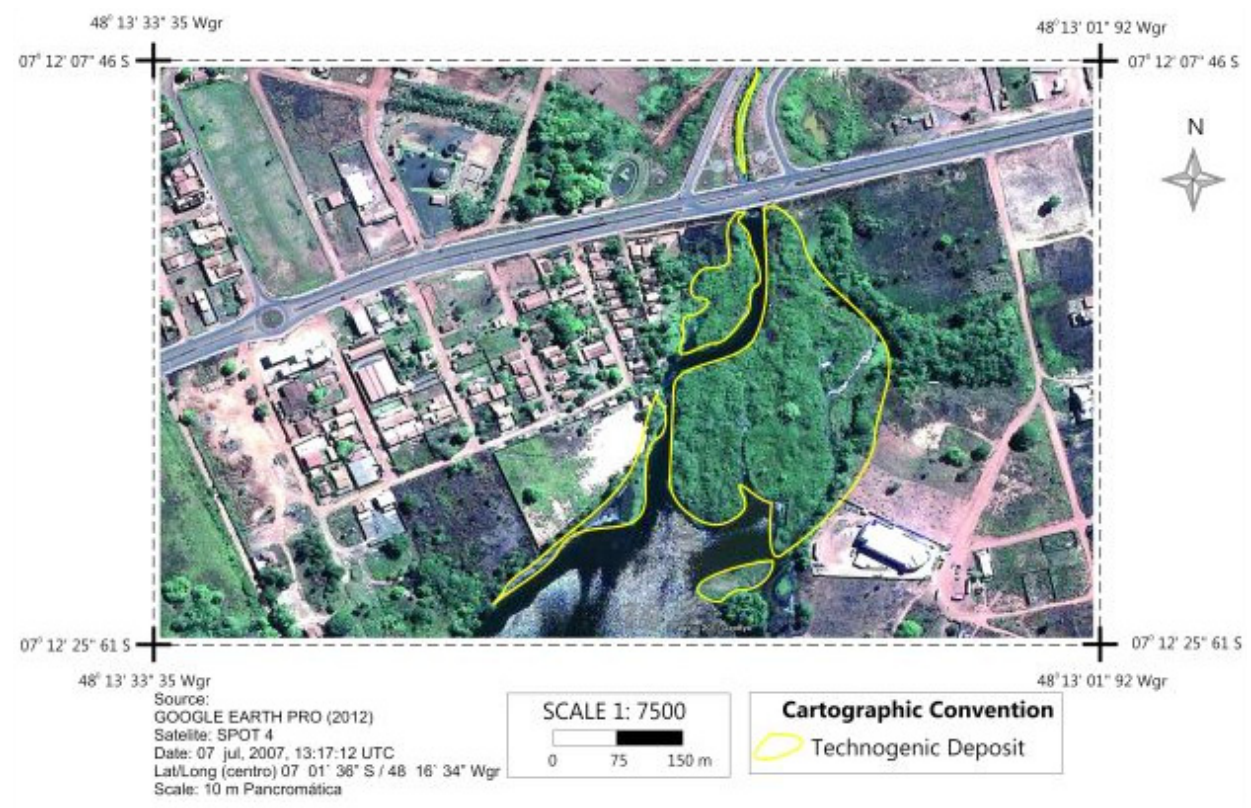

Fig. 6. Terrigenuos fluvial technogenous deposists, Neblica creek (2007) (MACHADO 2012).

Fig. 6. Depósitos fluviales terrígenos tecnogénicos, en cauce Neblina (2007) (MACHADO 2012).

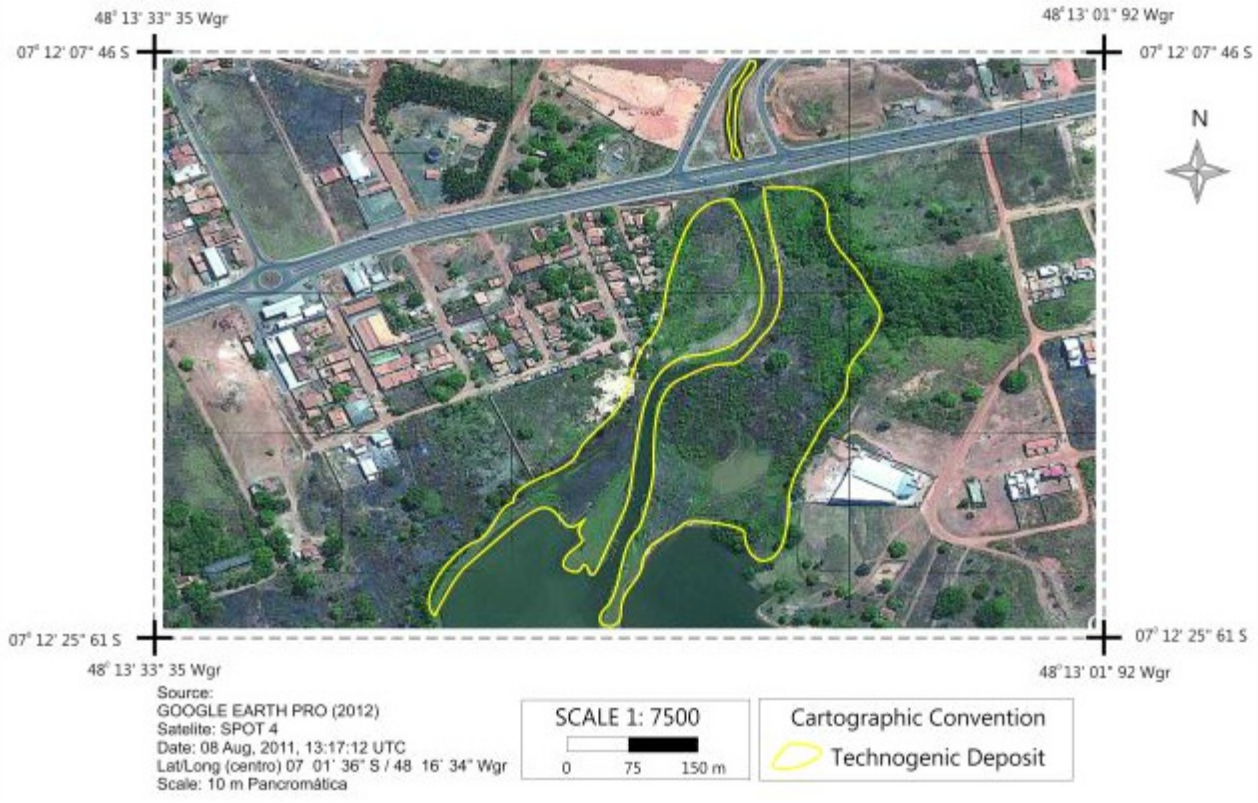

Fig. 7. Terrigenuos fluvial technogenous deposists, Neblica creek (2011) (MACHADO 2012).

Fig. 7. Depósitos fluviales terrígenos tecnogénicos, en cauce Neblina (2011) (MACHADO 2012). 


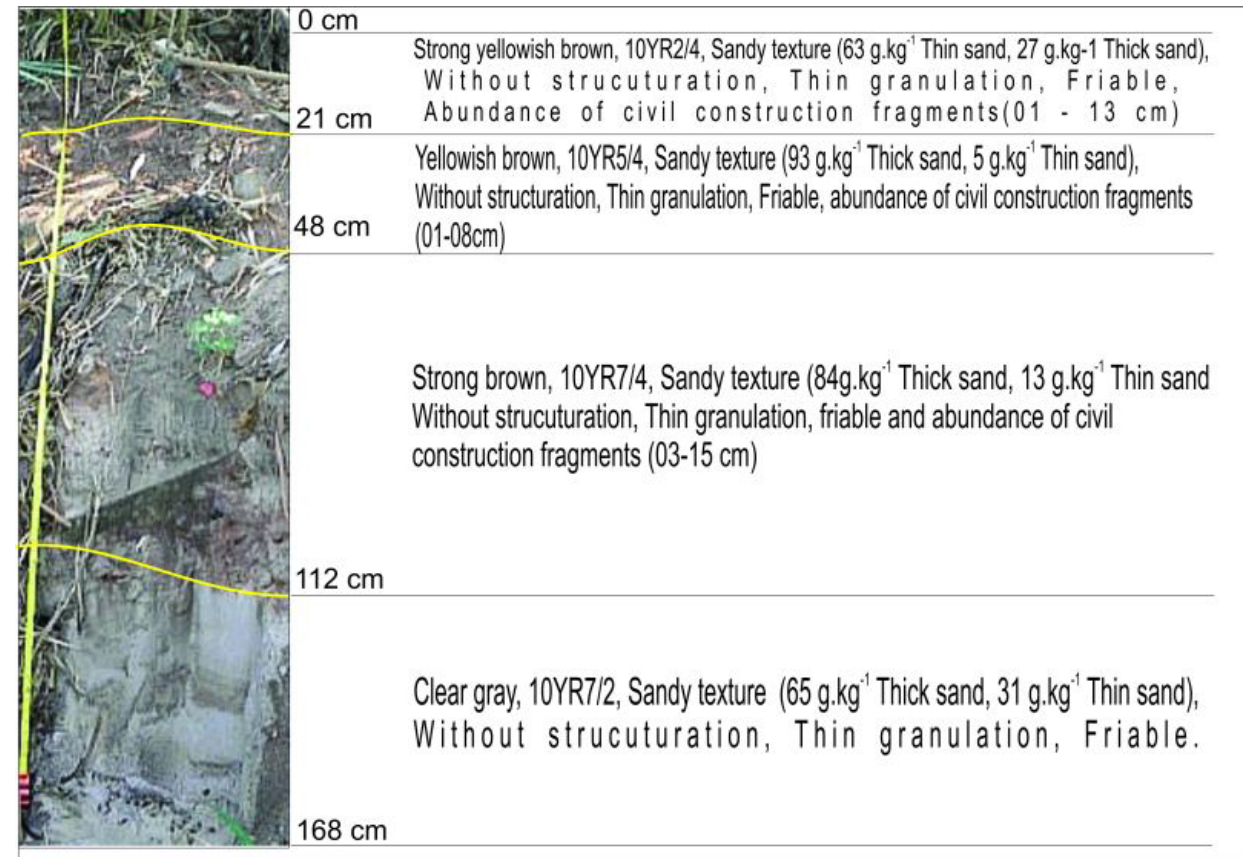

Fig. 8. Profile of inorganic fluvial technogenic deposit, Cimba Creek.

Fig. 8. Perfil de depósito tecnogénico fluvial inorgánico, en la corriente Cimba Coordinates: $7^{0}$ 11' 12" $06 \mathrm{~S}$ / 480 11'44" 07 Wgr / (MACHADO 2012).

The constant water action being it in the erosion, transportation and deposition of sediments in rainy seasons provoke a faster decomposition of small fragments that are predominant in almost all of the layers.

The entrainment for the river channel of sandy sediments of the Quartz-sand Neosol and clayish soil form sediment bars stabilized by vegetation adapted to the pollution conditions with the constant siltation. As the amount of sediments received by the brook was not enough, various organic and inorganic pollutants are added to this scenery, besides the great amount of solid remnants and construction materials that are discarded next to the brooks for landfill and compacted for civil work, which promote a great heterogeneity of materials that form the fluvial technogenic deposits.

\section{DISCUSSION}

The identification, location and stage of decomposition and incorporation of the deposits in the many types of areas facilitate the decisions taken by the public administration regarding the recovery and reduction of the problems related to these artificial bodies, in order to highlight the areas that may suffer from mass movement and chemical pollution. The great variety of types of areas for deposit requires a different treatment for the mitigation measures, emphasizing the fact that the increase in the urbanization in Brazil and in the world has been intensifying the creation and expansion of the technogenic deposits.

The remnants deposited in an irregular way cause inundations, diseases, interdiction of 
some ways and degradation of the urban area. Besides these consequences, the removal of the remnants accumulated in an irregular way burdens the public economy.

The oldest deposits in the city of Araguaína present an advanced decomposition of materials, mainly with organic products. The deposits in which the inorganic materials are dominant, present crust formations resulting from the dissolution of the civil construction remnants that make the water infiltration more difficult. Due to the decomposition, the material has suffered an accommodation guaranteeing a better stability against the action of the pluvial water, mainly in flat areas. The analyzed Technogenic Deposits where the clayish soil is dominant have small dimensions (< $100 \mathrm{~m}^{2}$ ) and short depth.

Older technogenic deposits have a higher concentration of organic material and the most recent ones have a bigger concentration of the inorganic material. In some areas, the removal, remobilization and addition of materials form a small but extensive superficial coat over the pedological cover. The artificial bodies incorporate to the local area covered by the sedimentation in the wetlands and with hard detection due to the vegetation. In the city of Araguaina, the technogenic materials present a huge difficulty in treatment due to the high variety of materials and the presence of houses.

The technogenic deposits in aquatic areas have great mobility of materials due to the water force and the great amount of organic materials facilitates the development of a vegetation. The high rainfall and temperatures in the Amazon make the available material very unsteady and subject to skid and sinking, even in lighter inclinations, due to the fast decomposition of the organic fraction.

\section{CONCLUSION}

The first results point at a great difficulty in identifying the satellite images in order to verify the variation in the behavior of the materials in the different types of environments, structure in the unsteady deposits in rainy seasons and application of recovery techniques for each case.

The techniques used for treating the urban remnants can be in situ, (vertical barriers) in which the actions for treating the polluting substance is made in the soil and ex situ (removal and treatment) that involves the removal of the material for treatment. For each situation the cost, efficacy and duration of the action should be considered.

The fast growth in the urban area of Araguaína in the last decade has increased the price of the lots, raising difficulties for the poor people to buy lots; so these people ended up invading or acquiring lots in improper areas as the wetlands, hillsides and areas with technogenic deposits. The areas with technogenic deposits would be essential for the public administration to adopt the following actions:

- removal and replacement of the people who live in those areas;

- prohibition of wastelands in urban lots with remnants from the civil construction and urban garbage;

- mapping and dissemination of the necessary information about the risky areas;

- inspection to curb the invasion and illegal deposition of remnants in these areas;

The reduction of the generation and final destination of the urban solid remnants should be a priority among the public policies for recycling. Some Brazilian cities have systems that produce artifacts that can be used in civil construction and urban 
pavement with environmental, social and economic benefits.

The illegal discard of materials would be solved through measures aiming at removing and sending the remnants to proper areas or re-using the civil construction and domestic remnants. In order to reduce the volume of the remnants, an implementation of educational projects in companies would be necessary so that the local population would be more aware about the importance of reducing the domestic garbage and wouldn't discard it in wastelands anymore. These educational projects should be permanent, because the results are usually obtained after a medium or long period.

\section{REFERENCES}

ASSOCIAÇÃO BRASILEIRA
NORMAS TÉCNICAS (ABNT), 2004. Resíduos Sólidos: Classificação. In: http:// http://www.aslaa.com.br/legislacoes/ NBR\%20n\%2010004-2004

BOSCOV, M.E.G., 2008. Geotecnia Ambiental. São Paulo, Oficina de Textos.

CHEMEKOV, Y.F., 1983. Technogenic Deposits. In: Inqua Congress, 11, Moscow, 1983, Abstracts, 3, 62.

CSIMA, P., 2010. Urban Development and Anthropogenic Geomorphology. In: SZABÓ, J., Lóránt, D \& L. Denes. (Eds). Anthropogenic Geomorphology, London: $179-187$.

FANNING, D.J \& M.C.B. FANNING, 1989. Soil: Morphology, Genesis and Classification. New York, John Wiley \& Sons.

GOUDIE, A., 2006. Human Agency in Geomorphology. In: Goudie A. The Human Impact on Natural Environment: Past, Present and Future. Oxford: Blackwell, 159.
LEHMANN, A \& K. STAHR, 2007. Nature and Significance of Anthropogenic Urban Soils. Journal of Soils and Sediments, 7 (4): 247-260.

MACHADO, C.A \& V.M. OLIVEIRA, 2005. Planejamento Ambiental Para a Cidade de Araguaína (TO). Revista Interface, 2(2): 52-65.

MACHADO, C.A., L.E. BOVOLATO \& L.S. GUEDES, 2008. Características Fisiográficas da Cidade de Araguaína. In: Estudos Multidisciplinares para a Educação Ambiental: $\mathrm{O}$ Tocantins em Destaque. SILVA, N. L. (Eds.), Universidade Federal de Tocantins, Goiânia, 11-30.

MACHADO, C.A \& S.C. RODRIGUES, 2011. Alternativas Ambientais, Econômicas e Sociais aos Impactos dos Depósitos Tecnogênicos na Cidade de Araguaína (TO). In: Anais do XIV Simpósio de Geografia Física Aplicada, Dourados: 1-8.

MACHADO, C. A \& S.C. RODRIGUES, 2011. Genesis and Dynamics of Technogenic Deposits in the Urban Area of Araguaína (Brazil). In: Actas de la Conferencia de la Unión Geográfica Internacional (UGI), Santiago, Chile, 201.

MACHADO, C.A., 2012. Gênese e Morfologia de Depósitos Tecnogênicos na Área Urbana de Araguaína (TO). Tese de Doutoramento, Universidade Federal de Uberlândia (UFU).

NEBER, A., J. AUBEL., F. CLASSON., S. HOEFER., A. KUNZ \& H.G. SOBISCH, 2006. From The Devonian to the Present: Landscape and Technogenic Relief Evolution in Urban Environment. In: $\mathrm{X}$ Congress of International Association of Engineering Geology, 517: 01-12.

OLIVEIRA, A.M, 2005. Tecnógeno: Registro da Ação Geológica do Homem. In: Quaternário do Brasil. SOUZA, C. R. de G. (Eds.). Ribeirão Preto (SP): Holos, 363-378. 
PLANO DIRETOR MUNICIPAL DE ARAGUAÍNA, 2005. Araguaína (TO), Brazil.

SILVA, C.P., A.B. RODRIGUES \& M.S.A. DIAS, 2007. Percepção de caieiros quanto às consequências do trabalho no processo saúde-doença. Revista de Saúde Pública, 41(5): 858-60.

SUGUIO, K., 1973. Introdução a Sedimentologia. Ed. Blucher, São Paulo.
TER-STEPANIAN, G., 1988. The Beginning of Technogene. Bulletin of International Association of Enginnering Geology, 38: 133-142.

TOCANTINS (ESTADO), 2004. Secretaria do Planejamento e Meio Ambiente. Projeto de Gestão Ambiental Integrada da Região do Bico do Papagaio. Zoneamento Ecológico-Econômico. Análise Ambiental e Socioeconômica: Norte do Estado do Tocantins. Palmas.

\section{Imagen de Investigaciones GEOGRÁFICAS}

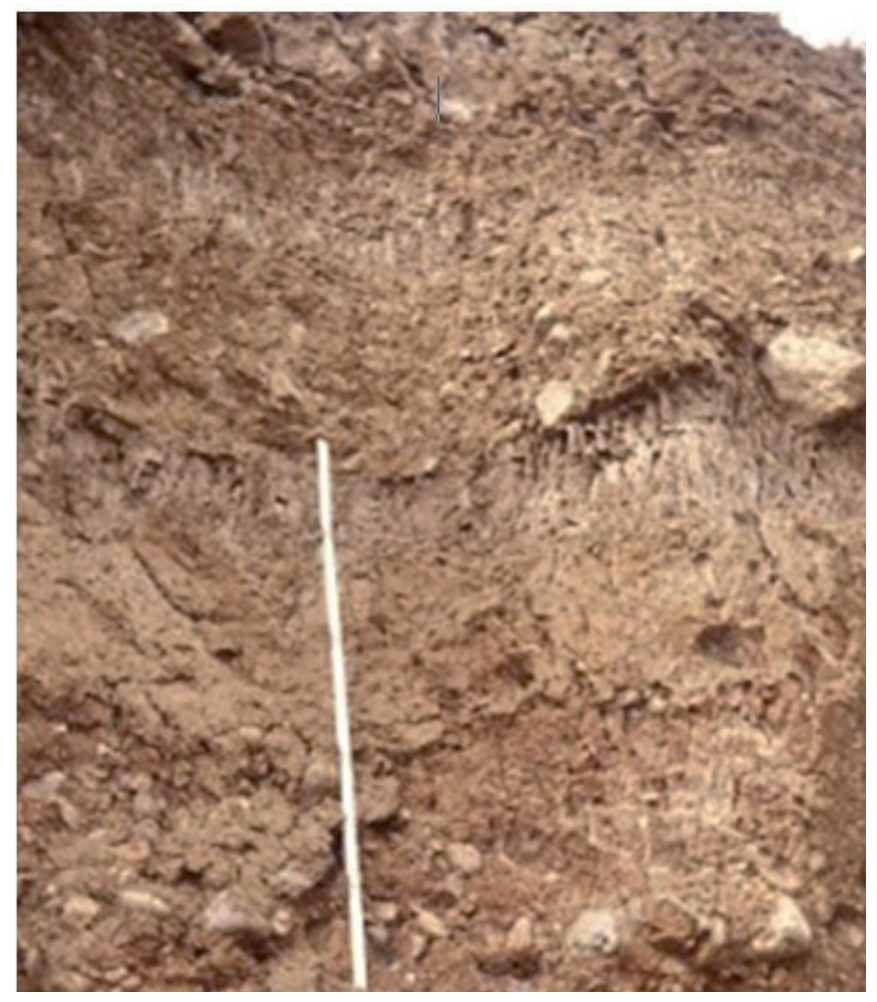

Valle del río Illapel, Chile: Secuencia de paleosuelos cuaternarios sobre terraza fluvial antigua mostrando horizontes B, de estructura prismática columnar. Indicación de sucesión de edades biostáticas y rexistáticas posteriores a la formación de la terraza (foto e interpretación de J.F. Araya Vergara). CInvest. Geogr. Chile. 